\title{
Two new species of Graphis (Ascomycota: Ostropales: Graphidaceae), from the Indo-Burma biodiversity hotspot
}

\section{Singh $\mathbf{P}^{1}$ and Singh $\mathbf{K} \mathbf{P}^{1}$}

${ }^{1}$ Botanical Survey of India, Central Regional Centre, Allahabad-211 002, India.

Singh P and Singh KP 2014 - Two new species of Graphis (Ascomycota: Ostropales: Graphidaceae), from Indo-Burma biodiversity hotspot. Mycosphere 5(4), 504-509, Doi 10.5943/mycosphere/5/4/2

\begin{abstract}
Graphis manipurensis and Graphis sirohiensis are described as new lichenized fungi from Manipur in the Indo-Burma biodiversity hotspot. Graphis manipurensis is characterized by its very short and unbranched lirellae (cleistomma-morph), entire labia, laterally carbonized excipulum, heavily inspersed hymenium, 1-spored asci with muriform ascospores and presence of norstictic acid. Graphis sirohiensis is characterized by its prominent lirellae (marginata-morph), entire labia, completely carbonized excipulum, heavily inspersed hymenium, 8-spored asci with submuriform to muriform ascospores and presence of norstictic acid.
\end{abstract}

Key words - Graphidaceae, Manipur, new species, lichens, taxonomy

\section{Introduction}

The state of Manipur in the north east India and part of the Indo-Burma biodiversity hotspot (Myers et al. 2000) is an interesting area for lichen research. Müller (1892) was the first worker who described 29 new taxa out of 101 taxa now reported from the state. Subsequently, some more publications were made by Singh (1980a, b, c, 1981a, b, 1982, 1983, 1984, 1986) from the same area. While studying Graphidaceae collections from Manipur (Fig. 1), two new species of Graphis were discovered. The genus as circumscribed by Staiger (2002), Lücking (2009) and Lücking et al. (2009) is characterized by its crustose thallus with trentepohlioid photobiont; simple to branched, rounded to lirellate or rarely pseudostromatic ascomata with apically, laterally or completely carbonized exciple; clear or inspersed hymenium, I- with simple paraphyses; nonamyloid, unitunicate 1-8 spored asci with apically thickened wall; and hyaline, transversely septate to muriform and amyloid ascospores with lens shaped lumina. It is widely distributed in tropical and subtropical regions, with at least one species in temperate regions, and represented by 125 species (Singh \& Sinha 2010, Chitale et al. 2011, Singh \& Swanlatha 2011 a, b) in India out of c. 368 species known from the world (Lücking et al. 2009; Bárcenas-Peñta et al. 2014). Two further new species Graphis manipurensis and Graphis sirohiensis -are described below.

\section{Materials \& Methods}

Specimens collected from Manipur and deposited in CAL herbarium were investigated. Morphological observations were made using a stereomicroscope (Nikon SMZ 1500). Thin hand- 
cut sections of thalli and ascomata were mounted in water, lactophenol cotton blue (LPCB), $10 \%$ $\mathrm{KOH}$ and Lugol's iodine solution. All anatomical measurements were taken in water mounts and examined under a compound microscope (Nikon Eclipse 50i). Lichen substances were identified by thin layer chromatography (TLC) in solvent A (180 Toluene: 60 dioxane: 8 acetic acid) following White \& James (1985).

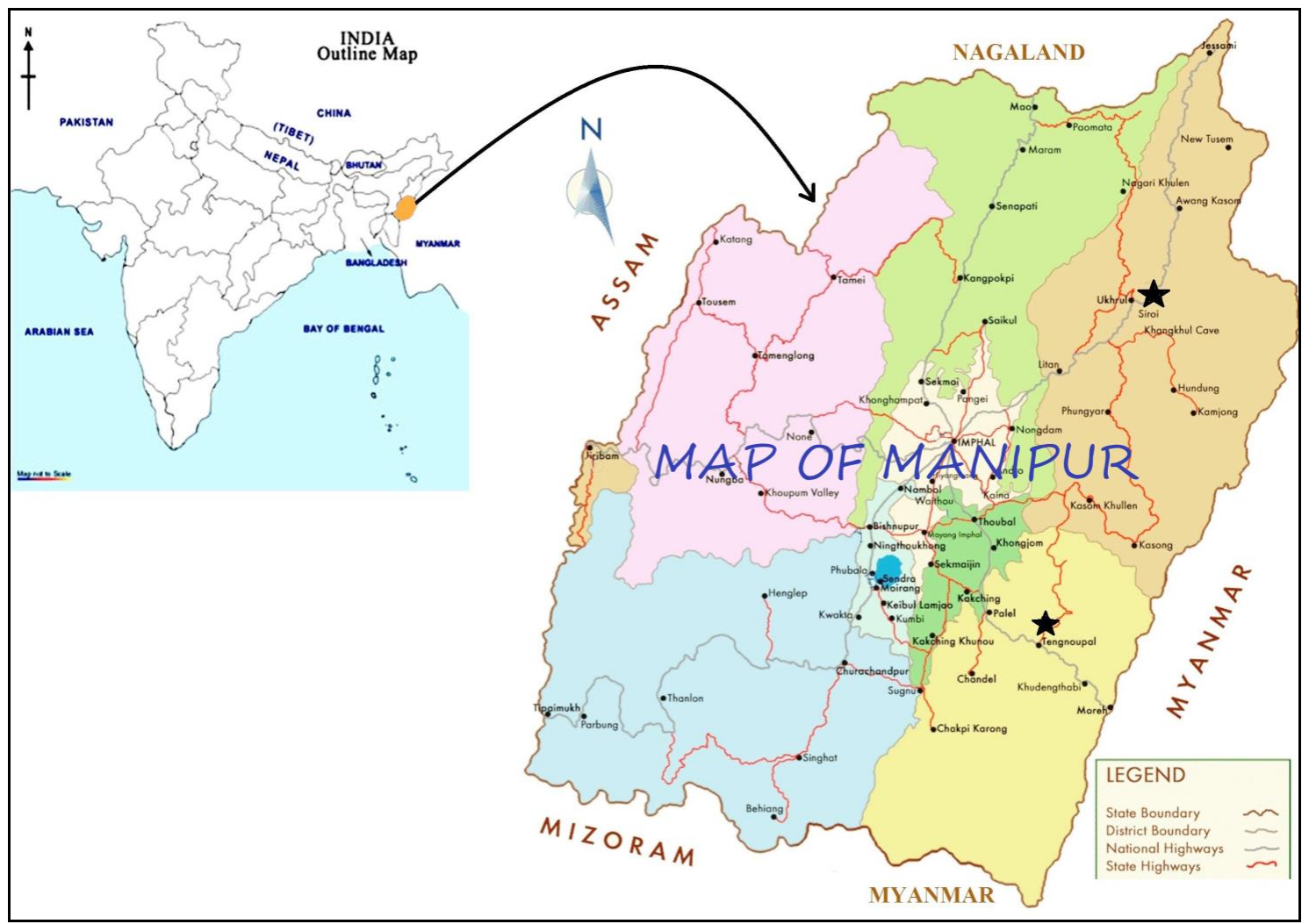

Fig 1. Study area, Manipur state, India

1. Graphis manipurensis Pushpi Singh \& Kr. P. Singh, sp. nov.

Fig. 2 A-E

MycoBank: MB 809433 described.

Etymology - The species epithet refers to the state from where the new species is being

Holotype: India, Manipur, Chandel district, Tengnoupal, $24^{0} 38^{\prime} 2^{\prime \prime} \mathrm{N} ; 94^{0} 15^{\prime} 2^{\prime \prime}$ E, on the bark of unidentified phorophyte, alt. c. 1550 m, K.P. Singh 550923 (Holotype-CAL).

Differing from Graphis nadurina in the larger ascospores, from G. cleistomma and G. oryzaecarpa in the norstictic acid chemistry, and from $G$. insulana in the lirellae morphology.

Thallus corticolous, crustose, epiphloeodal, greyish brown to reddish brown, continuous, \pm rugulose, 3-6 cm across, 100-175 $\mu \mathrm{m}$ thick; cortex indistinct; algal cells compactly arranged forming a layer like zone, $40-60 \mu \mathrm{m}$ thick, below the algal layer patches of large hyaline crystals present; photobiont Trentepohlia, algal cells $8-10 \mu \mathrm{m}$ across; prothallus indistinct.

Apothecia lirelliform, very short and unbranched (cleistomma-morph), straight, erumpent to prominent, acute to obtuse at ends, apically covered by thick complete thalline margin, $0.8-1.4 \mathrm{~mm}$ long, $0.55-0.8 \mathrm{~mm}$ wide, $0.3-0.42 \mathrm{~mm}$ high; disc concealed; thalline margin concolourous with the thallus, encrusted with large clusters of calcium oxalate crystals; labia entire, convergent; exciple 
open to slightly closed at base, laterally carbonized, 80-110 $\mu \mathrm{m}$ thick, together with thalline margin 140-180 $\mu \mathrm{m}$ thick; epihymenium pale brown, 10-15 $\mu \mathrm{m}$ high; hymenium hyaline, heavily inspersed, 170-210 $\mu \mathrm{m}$ high, I-; paraphyses simple, dense, 1-1.5 $\mu \mathrm{m}$ thick; asci 1-spored, cylindrical, 130-180 × 24-30(-35) $\mu \mathrm{m}$, I-; ascospores colourless, ellipsoid, densely muriform, transversely (12-) 20-24 septate, longitudinally (3-)10-12 septate, (98-)100-135 × (20-)25-45 $\mu \mathrm{m}$, I+ violet blue.

Chemistry - Thallus $\mathrm{K}+$ yellow forming red crystal, $\mathrm{C}-, \mathrm{P}-$; UV-. TLC: Norstictic acid (major) present.

Remarks - The species is characterized by its greyish brown to reddish brown thallus, very short and unbranched lirellae (cleistomma-morph), completely covered by thick thalline margin, laterally carbonized excipulum with entire labia, strongly inspersed hymenium, 1-spored asci with large muriform ascospores and presence of norstictic acid. Morphologically, it closely resembles Graphis nadurina Aptroot, G. cleistomma Nyl. and G. oryzaecarpa Lücking, which all have clear hymenia. Further, G. nadurina differs in having smaller ascospores $(40-50 \times 14-16 \mu \mathrm{m}$, vide Lücking et al. 2009) whereas G. cleistomma and G. oryzaecarpa have a completely carbonized excipulum and lack lichen substances. Anatomically, it closely resembles Graphis insulana (Müll. Arg.) Lücking but differs in the lirellae morphology. The new species is known only from the type locality, where it grows on the bark of tree in open places.

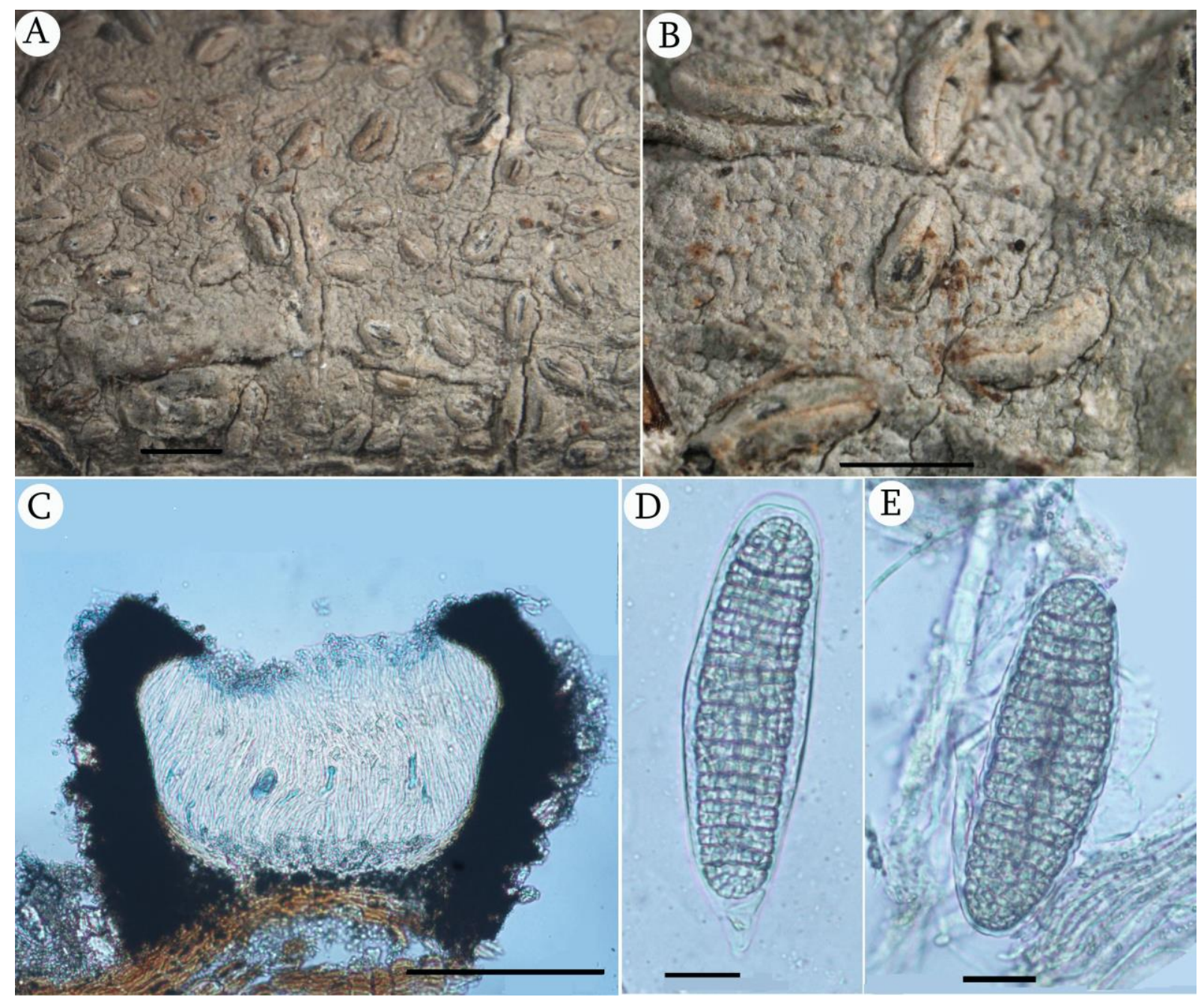

Fig. 2 A-E - Graphis manipurensis . A-B, habit; C, cross section of apothecium (in LPCB); D, ascus; $\mathrm{E}$, mature ascospores. - Bars $=\mathrm{A} \& \mathrm{~B}=1 \mathrm{~mm} ; \mathrm{C}=200 \mu \mathrm{m}$; D \& $\mathrm{E}=25 \mu \mathrm{m}$. 
MycoBank: MB 809435

Etymology - The species epithet refers to the name of the type locality from where the new species is collected.

Holotype: India, Manipur, Ukhrul district, $25^{\circ} 6^{\prime} 21.58^{\prime \prime} \mathrm{N} ; 90^{0} 27^{\prime} 25.89^{\prime \prime} \mathrm{E}$, on way to Sirohi hill, on the bark of tree, alt. c. 1650 m, K.P. Singh 54810 (holotype - CAL).

Differing from Graphis saxicola in the corticolous habit and has prominent lirellae with thin thalline margin.

Thallus corticolous, crustose, epiphloeodal, pale brown to yellowish brown, continuous, smooth to \pm rugulose, $4-6 \mathrm{~cm}$ across, $40-60 \mu \mathrm{m}$ thick; cortex indistinct; photobiont layer 30-45 $\mu \mathrm{m}$ thick; photobiont Trentepohlia, algal cells $6-8 \mu \mathrm{m}$ across; $\mu \mathrm{m}$ thick; prothallus indistinct.
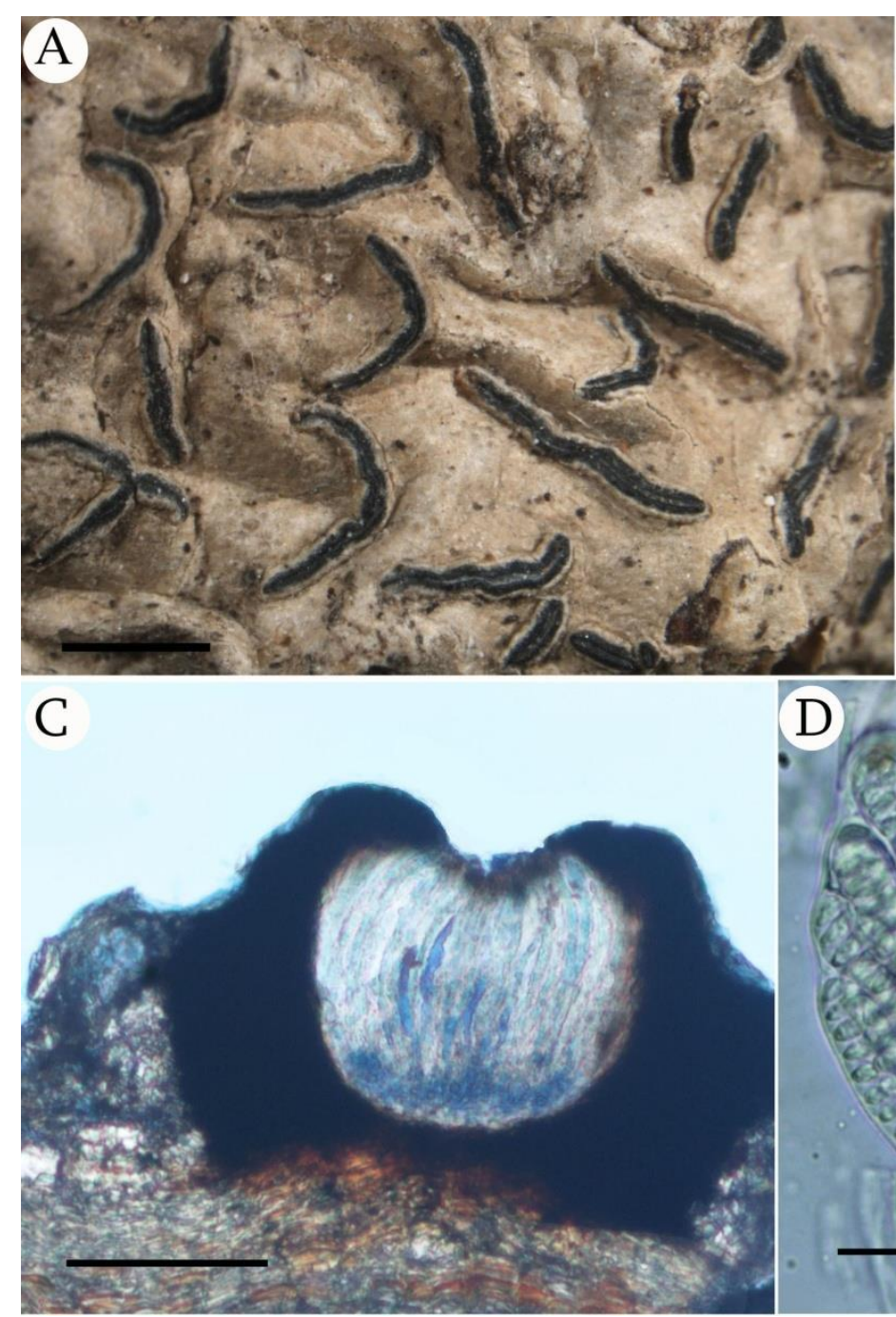

B
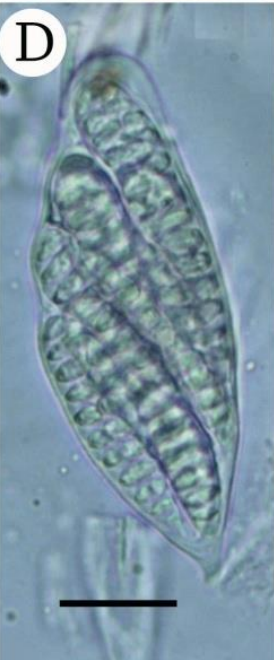

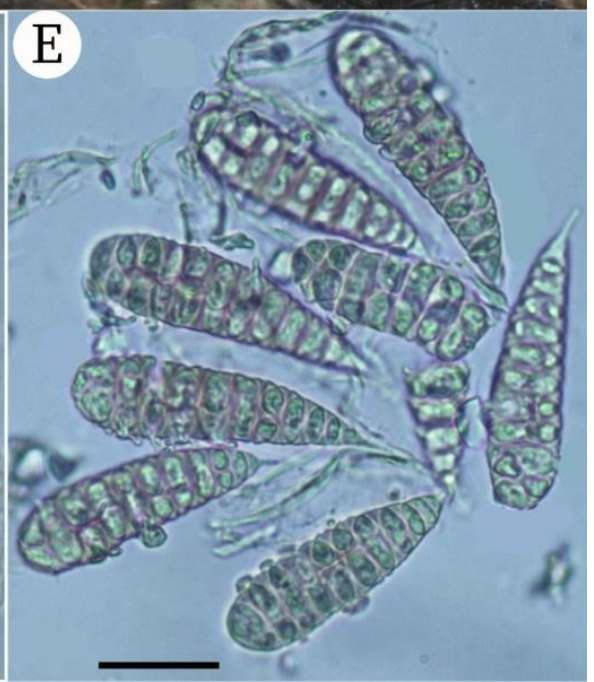

Fig. 3 A-E - Graphis sirohiensis. A-B, habit. C, cross section of apothecium (in LPCB). D, ascus. $\mathrm{E}$, mature ascospores. - Bars $=\mathrm{A} \& \mathrm{~B}=1 \mathrm{~mm} ; \mathrm{C}=200 \mu \mathrm{m}$; D \& E=20 $\mu \mathrm{m}$.

Apothecia lirelliform, black, unbranched to rarely triradiate, straight to \pm flexuose, prominent (marginata-morph); acute to obtuse at ends, laterally covered by thin thalline margin, $1.2-3 \mathrm{~mm}$ long, $0.35-0.56 \mathrm{~mm}$ wide, $0.25-0.42 \mathrm{~mm}$ high; disc concealed to partly exposed, blackish, epruinose; thalline margin concolourous with the thallus, encrusted with large clusters of 
calcium oxalate crystals; labia entire, convergent; exciple basally slightly open to closed, completely carbonized, 50-90 $\mu \mathrm{m}$ thick, together with thalline margin 95-160 $\mu \mathrm{m}$ thick; epihymenium pale brown, 8-15 $\mu \mathrm{m}$ thick; hymenium hyaline, heavily inspersed, 150-200 $\mu \mathrm{m}$ high, I-; paraphyses simple, dense, slightly clavate, pale brown at apices, $1-1.5 \mu \mathrm{m}$ thick,; asci 8-spored, clavate to cylindrical with biseriately arranged ascospores, 98-120(-140) $\times 24-30(-35) \mu \mathrm{m}$, I-; ascospores colourless, clavate, one end rounded and other end becoming narrower, submuriform to muriform, transversely (7-)10-11 septate, longitudinally 0-2 septate, (35-)40-51 × 10-13 $\mu \mathrm{m}$, I+ violet blue; young ascospores with thick epispore.

Chemistry: Thallus $\mathrm{K}-, \mathrm{C}-, \mathrm{P}-$; UV-. TLC: Norstictic acid (minor) present.

Remarks: Graphis sirohiensis is well characterized by its smooth, yellowish brown to pale brown thallus, prominent lirellae (marginata-morph) with laterally thick thalline margin, partly exposed disc, completely carbonized excipulum with entire labia, heavily inspersed hymenium, small, clavate, submuriform to muriform ascospores and presence of norstictic acid. Morphologically, anatomically and in chemistry, new species closely resembles Graphis handelii Zahlbr. and G. crebra Vain., but both later species differ in having transversely septate ascospores. In addition, G. crebra differs in having white pruinose disc. In general appearance, it also somewhat resembles G. ficicola Vain. and G. palmicola Makhija \& Adaw., which have clear hymenia, transversely septate ascospores, and different chemistry. It also resembles $G$. saxicola, in anatomy and chemistry and spore size, but differs in saxicolous habit and has erumpent lirellae with thick lateral thalline margin. The new species is known so far only from the type locality where it grows at an altitude of $c 1650 \mathrm{~m}$ on the bark of tree in open shady places.

\section{Acknowledgements}

The authors are thankful to Dr. Paramjeet Singh Director, Botanical Survey of India, Kolkata for encouragement and Head of Office, Botanical Survey of India, Central Regional Centre, Allahabad for facilities.

\section{References}

Bárcenas-Peñta A, Lücking R, Miranda-González R, Herrera-Campos MA. 2014 - Three new species of Graphis (Ascomycota: Ostropales: Graphidaceae) from Mexico, with updates to taxonomic key entries for 41 species described between 2009 and 2013. Lichenologist 46, 69-82.

Chitale G, Makhija U, Sharma B. 2011 - Additional species of Graphis from Maharashtra, India. Mycotaxon 115, 469-480.

Lücking R. 2009 - The taxonomy of the genus Graphis sensu Staiger: (Ostrapales: Graphidaceae). Lichenologist 41, 319-362.

Lücking R, Archer AW, Aptroot A. 2009 - A world wide key to the genus Graphis (Ostropales: Graphidaceae). Lichenologist 41, 363-452.

Müller Argoviensis J. 1982 - Lichenes Manipurensis, a cl. Dr. G. Watt circa Manipur ad limites orientales Indiae Orientalis 1881-82 lecti. J. Linn. Soc., Bot. 29, 217-231

Myers N, Mittermeier RA, Mittermeier CG, da Fonseca GAB., Kent J. 2000 - Biodiversity hotspots for conservation priorities. Nature 40, 853-858.

Singh KP. 1980a - Lichen genus Asterothyrium Müll. Arg. in India. Current. Science 48, 267268.

Singh KP. 1980b - Awasthiella, a new lichen genus from Manipur, India. Norw. J. Bot. 27, 33-35.

Singh KP. 1980c - Lichen genus Maronea Massal. from India. Geophytology 10, 34-36.

Singh KP. 1981a - Michrolichens from Manipur, India. Geophytology 11, 242-256.

Singh KP. 1981b - Macrolichens from Manipur, India. Biol. Mem 6, 145-168. 
Singh KP. 1983 - Catillaria manipuriensis, a new species of lichens and note on Lopadium austroindicum from India. Current Science 52, 165-166.

Singh KP, Singh SR. 1982 - Two new species of lichen genus Buellia from India. Geophytology.12, 126-129

Singh KP, Singh SR. 1984 - On the species of Buellia and Diplotomma from Manipur. Bull. Bot. Sur. Ind. 26, 62-64 (1985).

Singh KP, Sinha GP. 2010 - Indian Lichens: An Annotated Checklist. Botanical Survey of India. Kolkata.

Singh KP, Swarnlatha G. 2011a - New records of Graphis (Lichenized fungi) from India. Indian Journal of Forestry 34, 243-244.

Singh KP, Swarnlatha G. 2011b - A note on Graphidaceous lichens from Arunachal Pradesh, India. Indian Journal of Forestry 34, 353-360.

Singh KP, Upreti DK. 1986 - On the species of Cladonia from Arunachal Pradesh and Manipur, India, Geophytology. 16, 113-118.

Staiger B. 2002 - Die Flechtenfamilie Graphidaceae: Studien in Richtung einer natürlicheren Gliederung. Biblioth. Lichenol. 85, 1-526.

White FJ, James PW. 1985 - A new guide to the microchemical technique for the identification of lichen substances. British Lichen Society Bulletin 57 (supplement), 1-4. 